\title{
Design of an Overhead Tank for the Newly Built Guest House in Cit (Central Institute of Technology, Assam)
}

\author{
Amit Kumar Dey*1, Abhijit Dey ${ }^{\# 2}$, Mawfungra Brahma ${ }^{\# 3}$ \\ *Asst.Professor, Dept. of Civil Engineering, Central Institute of Technology, Kokrajhar, Assam, India \\ "Research Scholar, Dept. of Mechanical Engineering, National Institute of Technology, Silchar, Assam, India \\ ${ }^{\#}$ Dept. of Automobile Engineering,A.D Patel Institute of Technology, Gujarat, India \\ 1ak.dey@cit.ac.in \\ ${ }^{2}$ aad.mec.abhi@gmail.com
}

Abstract-An investigation was carried out to study the various losses of head in circular pipes. This was done in order to check the feasibility to design a tank for the guest house building for supplying water for domestic purposes in the building. Considering three peak times of water usage i.e. morning 7-9 am, afternoon 12-2 pm and evening 6-8 pm and assuming a certain number of plumbing fixtures to be in use at the same time, an effort was made to calculate the feasibility of the overhead tank. And after investigation this was found that the total head required for the overhead tank to be $18 \mathrm{~m}$. So a pump of 4.5 hp was proposed. Moreover as per analysis, it has been found and thus advisable to install an overhead tank of dimension $(5 \times 2.5) \mathrm{m}^{2}$ to meet the water requirements of the newly built guest house. And this requirement was found to be compatible in all the conditions those have been considered.

Key words: Head loss; flow in pipes; Discharge; Losses in pipes.

List of Symbols and Abbreviation

Symbol Description

$\begin{array}{ll}\text { D } & \text { Diameter } \\ \text { V } & \text { Velocity } \\ \rho & \text { Density } \\ \text { A } & \text { Cross-sectional area } \\ \text { Q } & \text { Discharge } \\ \mathrm{Re} & \text { Reynolds number } \\ \mathrm{f} & \text { Co-efficient of friction } \\ \mathrm{h}_{\mathrm{f}} & \text { Head loss due to friction } \\ \mathrm{f}^{\prime} & \text { Frictional resistance } \\ \Theta & \text { Angle of elevation } \\ \mathrm{w} & \text { Specific weight } \\ \mathrm{p} & \text { Pressure } \\ \mathrm{H} & \text { Head } \\ \mathrm{g} & \text { Specific gravity } \\ \mathrm{Z} & \text { Potential head }\end{array}$

HGL Hydraulic Gradient Line

\section{INTRODUCTION}

New Guest House is constructed in CIT (Central Institute of Technology, ASSAM) Campus to serve the guest of the CIT. It is situated beside the Teachers Quarter and to the east of Balagaon Transit Boys Hostel. The main objective of the analysis was to design an overhead tank with required head to supply water to the guest house building by calculating different head losses in pipes, assuming a certain number of plumbing fixtures to be in use at the same time. A pipe is a closed conduit which is used for carrying fluids under pressure. Pipes are commonly circular in section. As the pipe carry fluids under pressure, the pipes always run full. The fluid flowing in the pipes is always subjected to resistance due to shear forces between fluid particles and the boundary walls of the pipe and between the fluid particles themselves resulting from the viscosity of the fluid [1]. The resistance to the flow of the fluid is in general known as frictional resistance. Since certain amount of energy possessed by the flowing fluid will be consumed in overcoming this resistance to the flow, there will always be some loss of energy in the direction of flow, which however depends on the type of flow. The flow of 
the liquid in the pipe may be laminar, turbulent, or in a state of transition depending upon Reynolds number of flow [2-9].

However, turbulent flow can be very complex one that as yet has been defined a rigorous theoretical treatment. Since different laws govern these two types of flow in pipes, the same are required to be dealt separately. Moreover, the introduction of different diameters of pipes leads to the losses due to contraction or expansion of the pipes. Also the change in the gradient, if any, contributes to the overall losses of head [10-12].

\section{LOSSES IN PIPE FLOW}

\section{a. Head Loss}

Certain amount of energy proceed by the flowing fluid will be consumed in overcoming the frictional resistance of the flow, there will always be some loss of energy in the direction of flow. This energy loss results in reduction of head of the fluid and hence termed as head loss and can be classified as [15]:

\section{b. Major Losses}

The loss of head or energy due to friction in a pipe is known as major loss. As fluid flow through a pipe, resistance are experienced which results in reduction of velocity and ultimately the head. The friction being the predominant loss is of main concern. Head loss in pipes due to friction can be calculated using Darcy's Weisbach equation [16].

Loss of head (or energy) due to friction: Darcy-Weisbach equation

Considering a pipe having a cross-sectional area A carrying a fluid with a mean velocity V.

Let 1 and 2 be the two sections of the pipe, $\mathrm{L}$ distance apart. Let the intensities of the pressure be $\mathrm{P}_{1}$ and $\mathrm{P}_{2}$ respectively. By applying Bernoulli's equation between the sections 1 and 2, we obtain

$\frac{\mathrm{P}_{1}}{\mathrm{w}}+\frac{\mathrm{V}^{2} 1}{2 \mathrm{~g}}+\mathrm{Z}_{1}=\frac{\mathrm{P}_{2}}{\mathrm{w}}+\frac{\mathrm{V}^{2} 2}{2 \mathrm{~g}}+\mathrm{Z}_{2}+\mathrm{h}_{\mathrm{f}}$

Since $\quad \mathrm{V}_{1}=\mathrm{V}_{2}=\mathrm{V}$ and $\mathrm{Z}_{1}=\mathrm{Z}_{2}$

Loss of head $=h_{\mathrm{f}}=\left(\mathrm{p}_{1} / \mathrm{w}\right)-\left(\mathrm{p}_{2} / \mathrm{w}\right)$

i.e., the pressure intensity will be reduced by the frictional resistance in the direction of flow and the difference of pressure heads between any two sections is equal to the loss of head due to friction between these sections.

Further let $\mathrm{f}^{\prime}$ be the frictional resistance per unit area at unit velocity, then the frictional resistance

$=f^{\prime} \times$ area $\times V^{n}$

$=\mathrm{f}^{\prime} \times \mathrm{PL} \times \mathrm{V}^{\mathrm{n}}$

Where $\mathrm{P}$ is the wetted perimeter of the pipe.

The pressure forces at the sections 1 and 2 are $\left(\mathrm{p}_{1} \mathrm{~A}\right)$ and $\left(\mathrm{p}_{2} \mathrm{~A}\right)$ respectively.

Thus resolving all the forces horizontally, we get

$\mathrm{P}_{1} \mathrm{~A}=\mathrm{p}_{2} \mathrm{~A}+$ frictional resistance

$\left(\mathrm{p}_{1}-\mathrm{p}_{2}\right) \mathrm{A}=\mathrm{f}^{\prime} \times \mathrm{PL} \times \mathrm{V}^{\mathrm{n}}$

$\left(\mathrm{p}_{1}-\mathrm{p}_{2}\right)=\mathrm{f}^{\prime} \times(\mathrm{P} / \mathrm{A}) \times \mathrm{L} \mathrm{V}^{\mathrm{n}}$

Dividing both sides by the specific weight ' $w$ ' of the flowing fluid, we get

$\frac{\mathrm{p}_{1}-\mathrm{p}_{1}}{\mathrm{w}}=\frac{\mathrm{f}^{\prime}}{\mathrm{w}} \times \frac{\mathrm{P}}{\mathrm{A}} \mathrm{LV}^{2}$

$\mathrm{h}_{\mathrm{f}}=\frac{\mathrm{p}_{1}-\mathrm{p}_{2}}{\mathrm{w}}$ then

$h_{f}=\frac{f^{\prime}}{w} \times \frac{p}{A} \times L V^{n}$

The ratio of the cross-sectional area of the flow (wetted area) to the perimeter in contact with the fluid (wetted perimeter) i.e. (A/P) is called hydraulic mean depth (H.M.D) or hydraulic radius and it is represented by ' $\mathrm{m}$ ' or 'R'.

Then $\mathrm{h}_{\mathrm{f}}=\left(\mathrm{f}^{\prime} / \mathrm{w}\right) \times\left(\mathrm{LV}^{\mathrm{n}}\right)$

For pipes running full,

$\mathrm{m}=\frac{\mathrm{A}}{\mathrm{V}}=\frac{\pi \mathrm{D}^{2} / 4}{\pi \mathrm{D}}=\frac{\mathrm{D}}{4}$

Substituting this in the equation for $\mathrm{h}_{\mathrm{f}}$ and assuming $\mathrm{n}=2$,

$\mathrm{h}_{\mathrm{f}}=\frac{4 \mathrm{f}^{\prime}}{\mathrm{w}} \times \frac{\mathrm{LV}^{2}}{\mathrm{D}}$ 
Putting $\frac{4 \mathrm{f}^{\prime}}{\mathrm{w}}=\frac{\mathrm{f}}{2 \mathrm{~g}}$

$\mathrm{h}_{\mathrm{f}}=\frac{\mathrm{fLV}}{2 \mathrm{gD}}$

Where fis known as friction factor or co-efficient of friction, which is a dimensionless quantity.

The equation (i) is known as Darcy Weisbachequation which is commonly used for computing the loss of head due to friction in pipes. It may be noted that the head loss due to friction is also expressed in terms of velocity head $\left(\mathrm{V}^{2} / 2 \mathrm{~g}\right)$ corresponding to the mean velocity $[13,14]$. Further the observation shows that the coefficient ' $\mathrm{f}$ ' is not constant but its value depends on the roughness condition of the pipe surface and the Reynolds' number of the flow. As such, in order to determine the loss of head due to friction correctly, it is essential to estimate the value of $f$ correctly. For this purpose, on the basis of experimental observations the value have being developed, which indicate the manner in that $\mathrm{f}$ varies and also facilitate the correct estimation of the value of the friction factor $\mathrm{f}[5 . \mathrm{a}]$.

Hazen William's formula:

It is a formula which is widely used for designing water supply systems. According to this formula the mean velocity of flow is given by

$\mathrm{V}=0.85 \mathrm{C}_{1} \mathrm{R}^{0.63} \mathrm{~S}^{0.54}$

Where $\mathrm{C}_{1}$ is the co-efficient, the value of which depends on the value of boundary.

Some of the value of $\mathrm{C}_{1}$ is given below:

TABLE 1. Values of $\mathrm{C}_{1}$

\begin{tabular}{|c|c|c|}
\hline Sl. No & Type of pipe & Value of $\mathrm{C}_{1}$ \\
\hline 1 & Extremely smooth and straight & 140 \\
\hline 2 & Very smooth & 130 \\
\hline 3 & Smooth wood stove, smooth masonry & 120 \\
\hline 4 & New riveted steel & 110 \\
\hline 5 & Old riveted steel & 95 \\
\hline
\end{tabular}

\section{c. Hydraulic Gradient Line (H.G.L)}

It is defined as the line which gives the sum of pressure head $\left(\frac{\rho}{w}\right)$ and datum head $(\mathrm{z})$ of a flowing fluid in a pipe with respect to some reference line or it is the line which is obtained by joining the top of all vertical ordinates, showing the pressure head $(\mathrm{p} / \mathrm{w})$ of a flowing fluid in a pipe from the center of the pipe [5.b].

The following points are worth noting:

(1) Energy gradient line (E.G.L) always drops in the direction of flow because of loss of head.

(2) Hydraulic gradient line (H.G.L) may rise or fall depending upon the pressure changes.

(3) Hydraulic gradient line is always below the energy gradient line (E.G.L) and the vertical intercept between the two is equal to the velocity head $\left(\mathrm{V}^{2} / 2 \mathrm{~g}\right)$.

(4) For a pipe of uniform cross-section the slope of the hydraulic gradient line is equal to the slope of the energy gradient line.

(5) There is no relation whatsoever between the slope of energy gradient line and the slope of the axis of the pipe. 


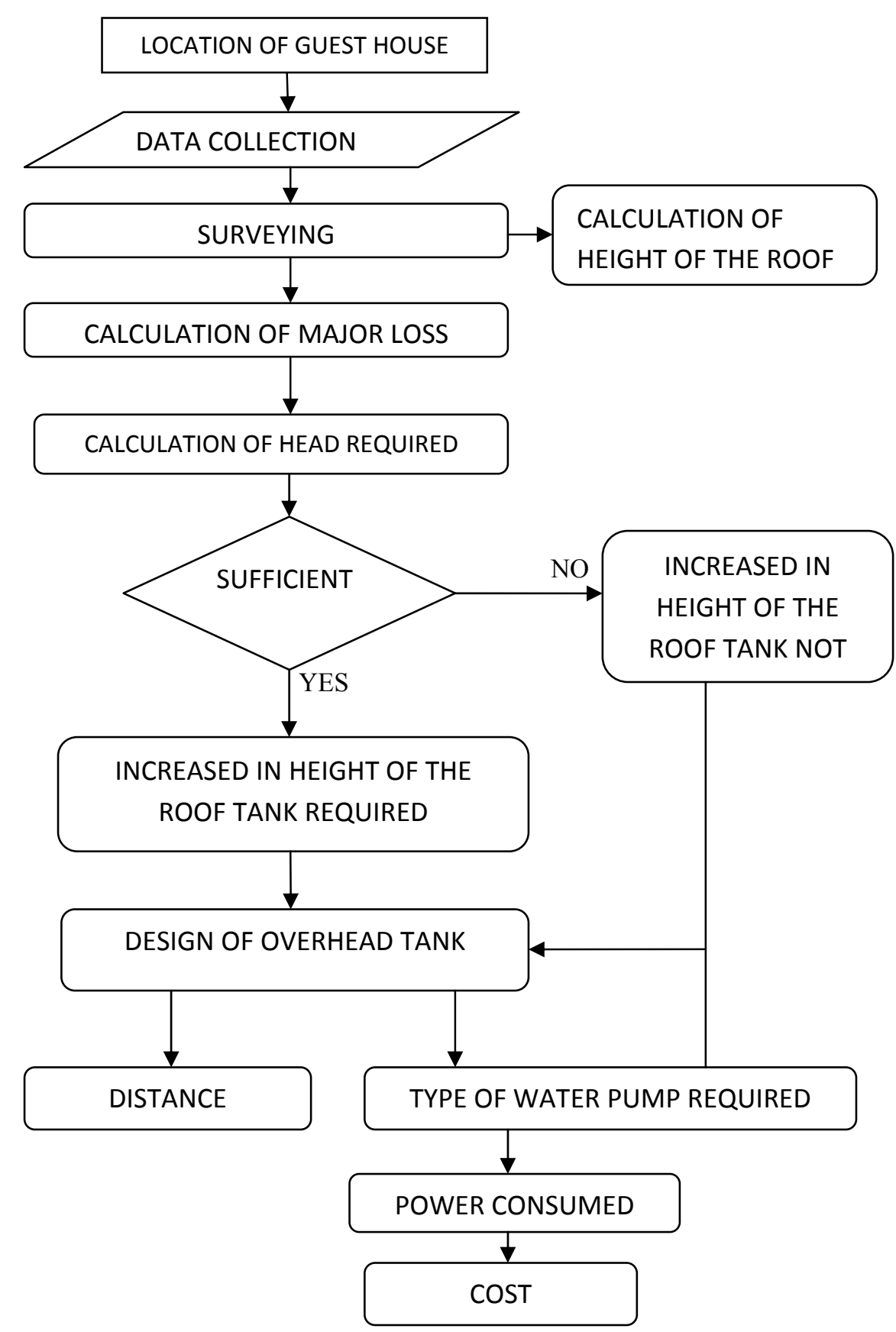

Fig.1.Flow chart of the activities of the study

\section{DESCRIPTIONS}

For the prosecution of analysis some data that cannot be practically known or calculated were required. For that reason these data's from different organizations, person or team concerned were enquired from Kokrajhar town. Various data's that are collected from different organization are tabulated below:

TABLE 2. Collected data

\begin{tabular}{|c|c|}
\hline DATA COLLECTED & ORGANIZATION \\
\hline Plan of the guest house building & Contractor \\
\hline Minimum head for different plumbing fixtures & Hardware Shop, Kokrajhar \\
\hline Electrical Ratings & Kokrajhar power house \\
\hline Rate of Pumps & Hardware Shop, Kokrajhar \\
\hline
\end{tabular}




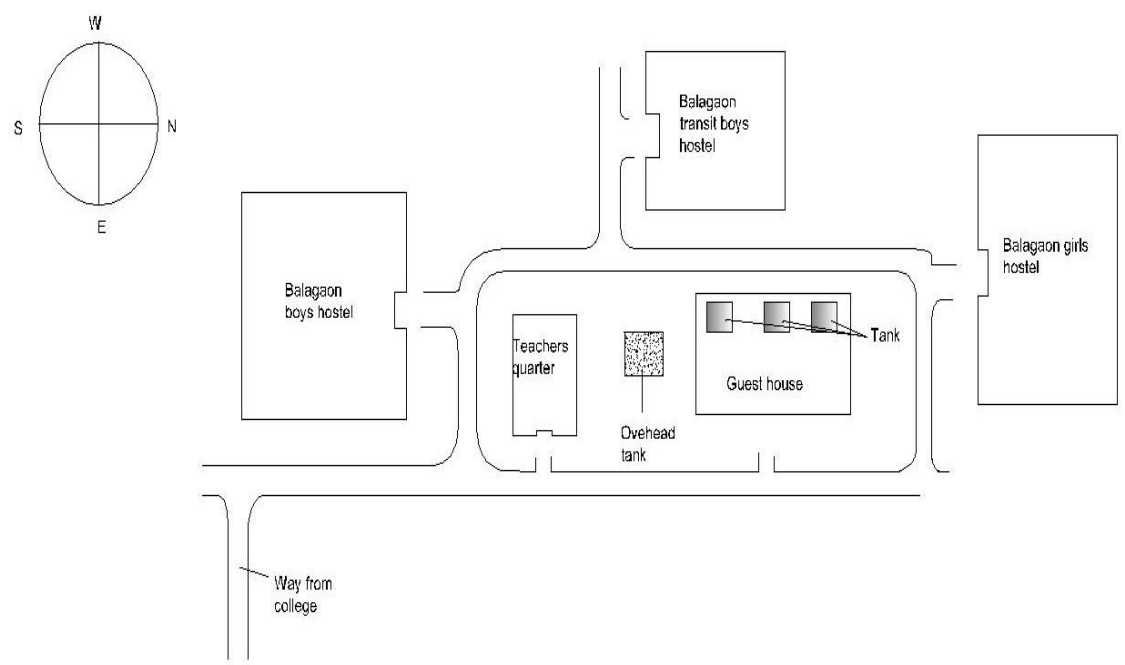

Fig. 2. Topography of the area under observation

\section{Surveying}

Measurement of the building (guest house, CIT)

$\Theta_{1}=13^{\circ} 23^{\prime} 5^{\prime \prime}$

$\Theta_{2}=1^{\circ} 43^{\prime} 33^{\prime \prime}$

$\mathrm{OC}=31.25 \mathrm{~m}$

Height of the tank $=31.25\left(\tan \Theta_{1}+\tan \Theta_{2}\right)$

$$
=8.38 \mathrm{~m}
$$

TABLE 3. Measurement of Tank Height

\begin{tabular}{|c|c|c|c|c|c|c|c|c|c|c|c|c|c|c|c|c|c|c|c|c|c|c|c|c|c|c|}
\hline \multirow{3}{*}{ 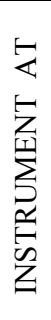 } & \multirow{3}{*}{ 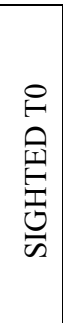 } & \multicolumn{11}{|c|}{ FACE:LEFT } & \multicolumn{11}{|c|}{ FACE:RIGHT } & \multirow{2}{*}{\multicolumn{3}{|c|}{$\begin{array}{l}\text { AVERAGE } \\
\text { VERTICAL } \\
\text { ANGLE }\end{array}$}} \\
\hline & & \multicolumn{3}{|c|}{$\mathrm{C}$} & \multicolumn{2}{|c|}{$\mathrm{D}$} & \multicolumn{3}{|c|}{ MEAN } & \multicolumn{3}{|c|}{$\begin{array}{l}\text { VERTICAL } \\
\text { ANGLE }\end{array}$} & \multicolumn{3}{|c|}{ A } & \multicolumn{2}{|c|}{ B } & \multicolumn{3}{|c|}{ MEAN } & \multicolumn{3}{|c|}{$\begin{array}{l}\text { VERTICAL } \\
\text { ANGLE }\end{array}$} & & & \\
\hline & & o & , & " & ' & "' & o & , & "' & o & , & " & o & ' & ", & , & ' & o & , & " & o & , & "' & o & ' & ' \\
\hline $\mathrm{O}$ & $\mathrm{A}$ & 1 & $\begin{array}{l}4 \\
4\end{array}$ & 5 & $\begin{array}{l}4 \\
3\end{array}$ & 10 & 1 & 43 & 37 & 1 & & 37 & 1 & $\begin{array}{l}4 \\
4\end{array}$ & 00 & 43 & $\begin{array}{l}0 \\
0\end{array}$ & 1 & $\begin{array}{l}4 \\
3\end{array}$ & 30 & 1 & $\begin{array}{l}4 \\
3\end{array}$ & 30 & 1 & $\begin{array}{l}4 \\
3\end{array}$ & $\begin{array}{l}3 \\
3\end{array}$ \\
\hline & $\mathrm{C}$ & 0 & 0 & 0 & 0 & 0 & 0 & 0 & 0 & 0 & c & 0 & 0 & 0 & 0 & 0 & 0 & 0 & 0 & 0 & 0 & 0 & 0 & 0 & 0 & 0 \\
\hline & B & $\begin{array}{l}1 \\
3\end{array}$ & $\begin{array}{l}2 \\
3\end{array}$ & $\begin{array}{l}1 \\
0\end{array}$ & $\begin{array}{l}2 \\
3\end{array}$ & 50 & 13 & 23 & 10 & 13 & & 10 & $\begin{array}{l}1 \\
3\end{array}$ & $\begin{array}{l}2 \\
3\end{array}$ & 00 & 23 & $\begin{array}{l}0 \\
0\end{array}$ & 13 & $\begin{array}{l}2 \\
3\end{array}$ & 00 & 13 & $\begin{array}{l}2 \\
3\end{array}$ & 00 & 13 & $\begin{array}{l}2 \\
3\end{array}$ & 5 \\
\hline
\end{tabular}

In S.I. units, the unit of viscosity is used as discussed below:

1 poise $=0.0102 \mathrm{~kg}-\mathrm{sec} / \mathrm{m}^{2}$

$=0.0102 \times 9.81$

$=0.1 \mathrm{~N}-\mathrm{sec} / \mathrm{m}^{2}$ 


\section{A. Effect of Temperature on Viscosity}

\section{RESULTS AND DISCUSSIONS}

The following table gives the values of viscosity of water at different temperatures [1].

TABLE 4. Viscosity at different temperature

\begin{tabular}{|c|c|c|}
\hline Temperature of & Coefficient of viscosity $(\mu)$ \\
\cline { 2 - 3 } water in ${ }^{\circ} \mathrm{C}$ & in kg-sec/m2 & in poise \\
\hline 0 & $183.2 \times 10-6$ & 0.01780 \\
5 & $151.7 \times 10-6$ & 0.01518 \\
10 & $133.2 \times 10-6$ & 0.01310 \\
20 & $102.3 \times 10-6$ & 0.01009 \\
30 & $81.80 \times 10-6$ & 0.00804 \\
40 & $66.50 \times 10-6$ & 0.00654 \\
60 & $47.90 \times 10-6$ & 0.00478 \\
80 & $36.30 \times 10-6$ & 0.00366 \\
100 & $28.80 \times 10-6$ & 0.00295 \\
\hline
\end{tabular}

TABLE 5. Practical Calculation for Major Losses

\begin{tabular}{|c|c|c|c|c|c|}
\hline $\begin{array}{c}\mathrm{A} \\
\text { (Area) }\end{array}$ & $\begin{array}{c}\mathrm{G} \\
\text { (gravity) }\end{array}$ & $\begin{array}{c}\rho_{\mathrm{m}} \\
\text { (density of } \\
\text { manometer) }\end{array}$ & $\begin{array}{c}\rho_{\mathrm{w}} \\
\text { (density of } \\
\text { water) }\end{array}$ & $\begin{array}{c}\mathrm{d} \\
\text { (dia. of pipe) }\end{array}$ & $\begin{array}{c}\mathrm{L} \\
\text { (length) }\end{array}$ \\
\hline $\begin{array}{c}0.77 \\
\mathrm{~m}^{2}\end{array}$ & $\begin{array}{c}9.81 \\
\mathrm{~m} / \mathrm{sec}^{2}\end{array}$ & $136000 \mathrm{~kg} / \mathrm{m}^{3}$ & $1000 \mathrm{~kg} / \mathrm{m}^{3}$ & $\begin{array}{c}0.022 \mathrm{~m} \text { (For pipe } \\
3 / 4 ")\end{array}$ & $\begin{array}{c}1.25 \mathrm{~m}(\text { For } 3 / 4 " \\
\text { pipe) } \\
1 \mathrm{~m} \text { (For } 1 / 2 " \\
\text { pipe) }\end{array}$ \\
\hline
\end{tabular}

TABLE 6. Observation data for larger pipe

\begin{tabular}{|c|c|c|c|c|c|}
\hline S.No & $\mathrm{h} 1, \mathrm{~cm}$ & $\mathrm{~h} 2, \mathrm{~cm}$ & $\mathrm{R} 1, \mathrm{~cm}$ & $\mathrm{R} 2, \mathrm{~cm}$ & $\mathrm{t}, \mathrm{sec}$ \\
\hline 1 & 15.5 & 12.4 & 6.20 & 6.8 & 13.62 \\
\hline 2 & 15.5 & 12.4 & 18.1 & 5.4 & 12.95 \\
\hline 3 & 15.5 & 12.4 & 23.9 & 9.8 & 15.06 \\
\hline AVERAGES & 15.5 & 12.4 & 16.07 & 7.33 & 13.88 \\
\hline
\end{tabular}

\section{Calculations}

$$
\begin{array}{lc}
\mathrm{R}=\mathrm{R} 1-\mathrm{R} 2 / 100 & =0.087 \mathrm{~m} \\
\mathrm{Q}=\mathrm{A} \times \mathrm{R} / \mathrm{t} & =4.83 \times 10^{-4} \mathrm{~m}^{3} / \mathrm{sec} \\
\mathrm{a}=\pi \mathrm{d}^{2} / 4 & =1.27 \mathrm{~m} / \mathrm{sec} \\
\mathrm{V}=\mathrm{Q} / \mathrm{a} & =0.031 \mathrm{~m} \\
\mathrm{~h}=\mathrm{h}_{1}-\mathrm{h}_{2} / 100 & =0.02 \\
\mathrm{f}=\mathrm{h}_{\mathrm{f}} 2 \mathrm{gd} /\left(4 \mathrm{LV}^{2}\right) & =0.39 \mathrm{~m} \\
\mathrm{~h}_{\mathrm{f}}=\mathrm{h}\left(\left(\rho \mathrm{m} / \rho_{\mathrm{w}}\right)-1\right) &
\end{array}
$$

Theoretical calculation for larger pipe:

$$
\begin{array}{ll}
\text { Temperature } & =27.8^{\circ} \mathrm{C} \\
\rho & =996.4 \\
\mathrm{~V}_{\text {act }} & =1.27 \mathrm{~m} / \mathrm{sec} \quad \text { (Taken from practical) } \\
\operatorname{Re} & =\rho v d / \mu \\
& =0.32 \times 10^{5} \\
\mathrm{f} & =0.079 / \mathrm{Re}^{1 / 4} \\
& =5.89 \times 10^{-3} \\
\mathrm{~h}_{\mathrm{f}} & =4 \mathrm{fLV}^{2} /(2 \mathrm{gD}) \\
& =0.11 \mathrm{~m}
\end{array}
$$


TABLE 7.Observation data for smaller pipe

\begin{tabular}{|c|c|c|c|c|c|}
\hline S1. .No & $\mathrm{h} 1, \mathrm{~cm}$ & $\mathrm{~h} 2, \mathrm{~cm}$ & $\mathrm{R} 1, \mathrm{~cm}$ & $\mathrm{R} 2, \mathrm{~cm}$ & $\mathrm{t}, \mathrm{sec}$ \\
\hline 1 & 18.4 & 9.5 & 16.7 & 8 & 9.56 \\
\hline 2 & 18.4 & 9.5 & 19.1 & 9.8 & 10.19 \\
\hline 3 & 18.4 & 9.5 & 28 & 9.4 & 21.37 \\
\hline AVERAGES & 18.4 & 9.5 & 21.27 & 9.06 & 13.71 \\
\hline
\end{tabular}

$$
\begin{array}{lc}
\mathrm{R}=\mathrm{R} 1-\mathrm{R} 2 / 100 & =0.122 \mathrm{~m} \\
\mathrm{Q}=\mathrm{A} \times \mathrm{R} / \mathrm{t} & =6.852 \times 10^{-4} \mathrm{~m}^{3} / \mathrm{sec} \\
\mathrm{a}=\pi \mathrm{d}^{2} / 4 & =3.406 \mathrm{~m} / \mathrm{sec} \\
\mathrm{V}=\mathrm{Q} / \mathrm{a} & =0.089 \mathrm{~m} \\
\mathrm{~h}=\mathrm{h}_{1}-\mathrm{h}_{2} / 100 & =0.026 \\
\mathrm{f}=\mathrm{h}_{\mathrm{f}} 2 \mathrm{gd} /\left(4 \mathrm{LV}^{2}\right) & =1.12 \mathrm{~m} \\
\mathrm{~h}_{\mathrm{f}}=\mathrm{h}\left(\left(\rho \mathrm{m} / \rho_{\mathrm{w}}\right)-1\right) &
\end{array}
$$

Theoretical calculation for smaller pipe:

$$
\begin{array}{ll}
\text { Temperature } & =27.8^{\circ} \mathrm{C} \\
\rho & =996.4 \\
\mathrm{~V}_{\text {act }} & =3.406 \mathrm{~m} / \mathrm{sec} \quad \text { (Taken from practical) } \\
\mathrm{Re} & =\rho \mathrm{vd} / \mu \\
& =0.64 \times 10^{5} \\
\mathrm{f} & =0.079 / \mathrm{Re}^{1 / 4} \\
& =4.97 \times 10^{-3} \\
\mathrm{~h}_{\mathrm{f}} & =4 \mathrm{fLV}^{2} /(2 \mathrm{gD}) \\
& =0.73 \mathrm{~m}
\end{array}
$$

\section{Calculation of losses due to friction for guest house}

Assuming the tank outlet to be a mouthpiece, actual velocity of the water at the exit is calculated by the formula$\mathrm{V}_{\text {act }}$

Where Depth of the tank $(\mathrm{H}) \quad=1.48 \mathrm{~m}$ $=0.855 \sqrt{ }(2 \mathrm{gH})$

Calculation of Reynolds Number

$$
\text { Re } \quad=(\rho v D) / \mu
$$

Where $\rho=$ specific wt. of water; $V=$ velocity of water; $D=$ dia. Of the pipe;

$\mu=$ dynamic viscosity

Calculation of friction factor ( $f$ )

If $\operatorname{Re}<2000, f=16$

$4000<\operatorname{Re}<10^{6}, \mathrm{f}$

Upto $10^{7}, \mathrm{f}$

$$
\begin{aligned}
& =0.079 /(\mathrm{Re})^{1 / 4} \\
& \quad=0.008+\left(0.05525 / \mathrm{Re}^{0.235}\right), \text { for smooth pipes. }
\end{aligned}
$$

Calculation of head loss due to friction $\mathrm{h}_{\mathrm{f}}$

$$
=4 \mathrm{fLV}^{2} /(2 \mathrm{gD})
$$

Power losses to maintain the flow.

$\mathrm{P}_{1}$

$\mathrm{Q}=$ Discharge $=\mathrm{V} . \mathrm{A}$

$$
=\left(\rho g \mathrm{Qh}_{\mathrm{f}}\right) / 1000
$$

Where A $=$ Cross-section area $=(1 / 4) \pi \mathrm{D}^{2}$

Assuming number of plumbing fixtures as shown below-
a. Three wash basin
b. Three shower
c. Two tap at water closet
d. Three tap at bathroom

Minimum Head at the top of the roof can be calculated from the Table below 
TABLE 8. Temperature vs. Specific weight for measuring Head

\begin{tabular}{|l|l|l|l|l|l|l|l|l|l|l|}
\hline $\begin{array}{l}\text { Temp of water } \\
\text { in deg.c }\end{array}$ & 4 & 10 & 15 & 21 & 26 & 32 & 37 & 43 & 49 & 65 \\
\hline $\begin{array}{l}\text { Specific weight } \\
\text { in } \mathrm{kg} / \mathrm{m}^{3}\end{array}$ & 1000 & 999.72 & 999 & 998 & 997 & 996 & 993 & 991 & 990 & 980 \\
\hline
\end{tabular}

1. Power required for overcoming residual head (when head loss due to friction $>$ head available) $\mathrm{P} 2=\left(\rho g \mathrm{Qh}_{2}\right) / 1000 \mathrm{KW}$

Where $\mathrm{h}_{2}=$ Total pressure residual head for the plumbing fixtures.

TABLE 9. Total residual Head for all plumbing fixtures

\begin{tabular}{|c|c|c|c|}
\hline SL NO & Plumbing Fixtures & No. of fixtures & Residual Head $(\mathrm{m})$ \\
\hline 1 & Wash Basin & 3 & $5.64 \times 3=16.92$ \\
\hline 2 & Shower & 3 & $8.45 \times 3=25.35$ \\
\hline 3 & 1 tap at W.C & 2 & $3.5 \times 2=7$ \\
\hline 4 & 1 tap at Bath room & 3 & $3.5 \times 3=10.5$ \\
\hline \multicolumn{3}{|c|}{ Total $=59.77$ or 5.43/fixtures } \\
\hline
\end{tabular}

Assuming eleven fixtures are used at a time in a house at the peak hour, therefore required head at the top of the roof of the quarters for the above fixtures equal to 59.77/11 i.e. 5.43m per fixtures. Assuming peak hours of flow through plumbing fixtures to the guest house to be 7 AM to 9 AM morning, 12 noon to 2 PM and 7 PM to $9 \mathrm{PM}$, the values of specific weight and dynamic viscosity will change as per table. Thus the head loss will also be a function of temperature.

Calculations for full tank in morning, afternoon and evening are tabulated below For middle tank ground floor (Here $\mathrm{L}=10.78 \mathrm{~m}$ )

Table 10. Data's for middle tank, ground floor, morning \& evening

\begin{tabular}{|c|c|c|c|c|}
\hline \multicolumn{5}{|c|}{$\mathrm{T}=23.8^{\circ}$, Morning \& Evening } \\
\hline $\begin{array}{c}\mathrm{V} \\
(\mathrm{m} / \mathrm{s})\end{array}$ & $\begin{array}{c}\mathrm{Q} \\
\left(\mathrm{m}^{3} / \mathrm{s}\right)\end{array}$ & $\operatorname{Re}$ & $\mathrm{F}$ & $\mathrm{h}_{\mathrm{f}}(\mathrm{m})$ \\
\hline 4.61 & 0.0042 & $\begin{array}{r}1.635 \\
\times 10^{5}\end{array}$ & $\begin{array}{c}3.93 \\
\times 10^{-3}\end{array}$ & 5.55 \\
\hline
\end{tabular}

For middle tank first floor $($ Here $\mathrm{L}=2.9 \mathrm{~m})$

TABLE 12. Data's for middle tank, ground floor, afternoon

\begin{tabular}{|c|c|c|c|c|}
\hline \multicolumn{5}{|c|}{$\mathrm{T}=28^{\circ}$, Afternoon } \\
\hline $\begin{array}{c}\mathrm{V} \\
(\mathrm{m} / \mathrm{s})\end{array}$ & $\begin{array}{c}\mathrm{Q} \\
\left(\mathrm{m}^{3} / \mathrm{s}\right)\end{array}$ & $\operatorname{Re}$ & $\mathrm{f}$ & $\mathrm{h}_{\mathrm{f}}(\mathrm{m})$ \\
\hline 4.61 & 0.0042 & $\begin{array}{c}1.799 \\
\times 10^{5}\end{array}$ & $\begin{array}{c}3.84 \times \\
10^{-3}\end{array}$ & 5.42 \\
\hline
\end{tabular}

For middle tank first floor (Here $\mathrm{L}=2.9 \mathrm{~m}$ )

TABLE 14. Data's for two side tanks ground floor, morning \& evening

\begin{tabular}{|c|c|c|c|c|}
\hline \multicolumn{5}{|c|}{$\mathrm{T}=23.8^{\circ}$, Morning \& Evening } \\
\hline $\begin{array}{c}\mathrm{V} \\
(\mathrm{m} / \mathrm{s})\end{array}$ & $\mathrm{Q}\left(\mathrm{m}^{3} / \mathrm{s}\right)$ & $\mathrm{Re}$ & $\mathrm{F}$ & $\mathrm{h}_{\mathrm{f}}(\mathrm{m})$ \\
\hline 4.61 & 0.0042 & $\begin{array}{c}1.635 \\
\times 10^{5}\end{array}$ & $\begin{array}{c}3.93 \times \\
10^{-3}\end{array}$ & 7.89 \\
& & & \\
\hline
\end{tabular}

For two side tanks first floor (Here $\mathrm{L}=15.34 \mathrm{~m}$ )
Table 11.Data's for middle tank, first floor, morning \& evening

\begin{tabular}{|c|c|c|c|c|}
\hline \multicolumn{5}{|c|}{$\mathrm{T}=23.8^{\circ}$, Morning \& Evening } \\
\hline $\mathrm{V}(\mathrm{m} / \mathrm{s})$ & $\mathrm{Q}\left(\mathrm{m}^{3} / \mathrm{s}\right)$ & $\mathrm{Re}$ & $\mathrm{F}$ & $\mathrm{h}_{\mathrm{f}}(\mathrm{m})$ \\
\hline 4.61 & 0.0042 & $\begin{array}{c}1.635 \\
\times 10^{5}\end{array}$ & $\begin{array}{c}3.93 \times \\
10^{-3}\end{array}$ & 1.49 \\
\hline
\end{tabular}

For middle tank ground floor $($ Here $\mathrm{L}=10.78$ )

Table 13. Data's for middle tank, first floor, afternoon

\begin{tabular}{|c|c|c|c|c|}
\hline \multicolumn{5}{|c|}{$\mathrm{T}=28^{\circ}$, Afternoon } \\
\hline $\mathrm{V}(\mathrm{m} / \mathrm{s})$ & $\begin{array}{c}\mathrm{Q} \\
\left(\mathrm{m}^{3} / \mathrm{s}\right)\end{array}$ & $\mathrm{Re}$ & $\mathrm{F}$ & $\mathrm{h}_{\mathrm{f}}(\mathrm{m})$ \\
\hline 4.61 & 0.0042 & $\begin{array}{c}1.799 \\
\times 10^{5}\end{array}$ & $\begin{array}{c}3.84 \times \\
10^{-3}\end{array}$ & 1.46 \\
\hline
\end{tabular}

For two side tanks ground floor (Here $\mathrm{L}=15.34 \mathrm{~m}$ )

Table 15. Data's for two side tanks first floor, morning \& evening

\begin{tabular}{|c|c|c|c|c|}
\hline \multicolumn{5}{|c|}{$\mathrm{T}=23.8^{\circ}$, Morning \& Evening } \\
\hline $\mathrm{V}(\mathrm{m} / \mathrm{s})$ & $\mathrm{Q}\left(\mathrm{m}^{3} / \mathrm{s}\right)$ & $\operatorname{Re}$ & $\mathrm{F}$ & $\mathrm{h}_{\mathrm{f}}(\mathrm{m})$ \\
\hline 4.61 & 0.0042 & $\begin{array}{c}1.635 \\
\times 10^{5}\end{array}$ & $\begin{array}{c}3.93 \times \\
10^{-3}\end{array}$ & 7.89 \\
\hline
\end{tabular}

For two side tanks ground floor (Here $\mathrm{L}=15.34 \mathrm{~m}$ ) 
TABLE 16. Data's for two side tanks ground floor, afternoon

\begin{tabular}{|c|c|c|c|c|}
\hline \multicolumn{5}{|c|}{$\mathrm{T}=28^{\circ}$, Afternoon } \\
\hline $\begin{array}{c}\mathrm{V} \\
(\mathrm{m} / \mathrm{s})\end{array}$ & $\mathrm{Q}\left(\mathrm{m}^{3} / \mathrm{s}\right)$ & $\mathrm{Re}$ & $\mathrm{f}$ & $\mathrm{h}_{\mathrm{f}}(\mathrm{m})$ \\
\hline 4.61 & 0.0042 & $\begin{array}{c}1.799 \\
\times 10^{5}\end{array}$ & $\begin{array}{c}3.84 \times \\
10^{-3}\end{array}$ & 7.71 \\
& & & \\
\hline
\end{tabular}

Table 17. Data's for two side tanks first floor, afternoon

\begin{tabular}{|c|c|c|c|c|}
\hline \multicolumn{5}{|c|}{$\mathrm{T}=28^{\circ}$, Afternoon } \\
\hline $\mathrm{V}(\mathrm{m} / \mathrm{s})$ & $\mathrm{Q}\left(\mathrm{m}^{3} / \mathrm{s}\right)$ & $\mathrm{Re}$ & $\mathrm{f}$ & $\mathrm{h}_{\mathrm{f}}(\mathrm{m})$ \\
\hline 4.61 & 0.0042 & 1.799 & $3.84 \times$ & 7.71 \\
& & $\times 10^{5}$ & $10^{-3}$ & \\
\hline
\end{tabular}

For two side tanks first floor (Here $\mathrm{L}=15.34 \mathrm{~m}$ )

From the above tables, the average head of guest house $=5.66 \mathrm{~m}$

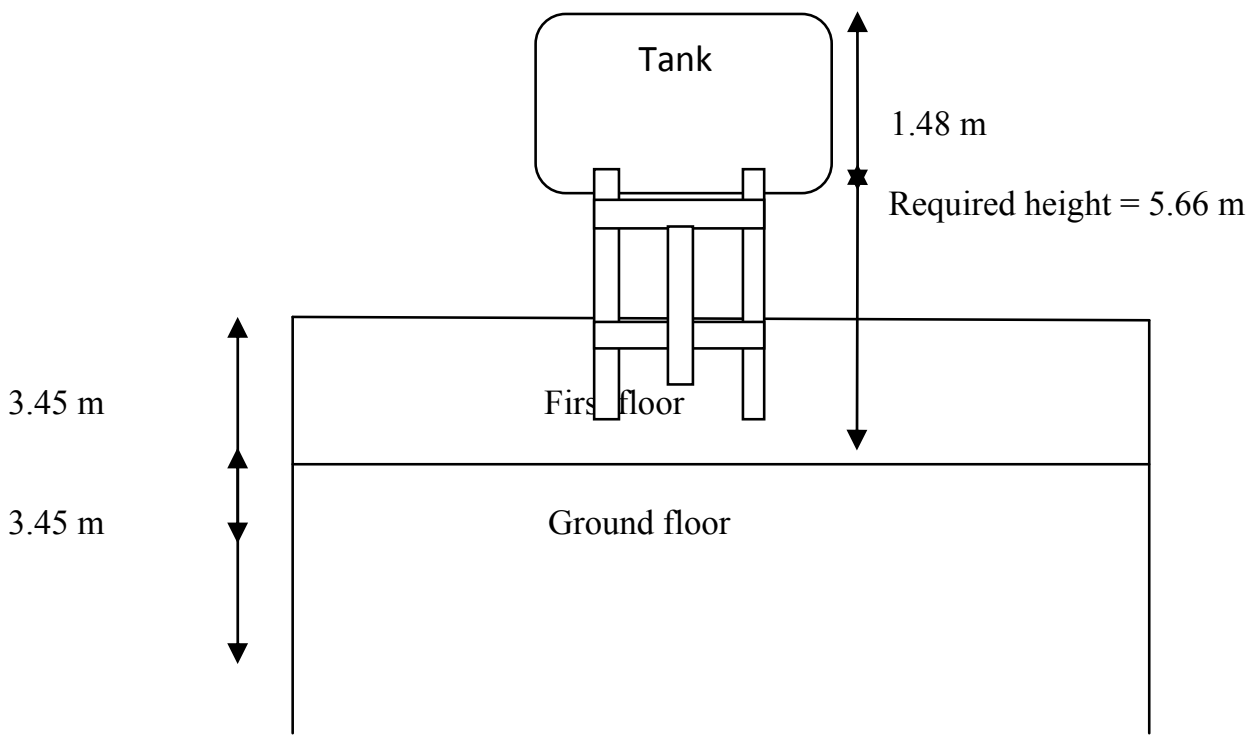

Fig. 4. Height of guest house tank

Therefore total height of guest house tank $=(3.45+3.45+5.66+1.48) \mathrm{m}=14.04 \mathrm{~m}$

\section{DESIGN OF OVERHEAD TANK}

Since, Discharge (Q)

Total volume of water required for $2 \mathrm{hrs}$

Let, Length (L)

Height $(\mathrm{H})=$ Breadth $(\mathrm{B})$

$\mathrm{L} \times \mathrm{B} \times \mathrm{H}$

$2 \mathrm{~B}^{3}$

Therefore, B

$\mathrm{L}$

$\mathrm{H}$

Check: $\mathrm{L} \times \mathrm{B} \times \mathrm{H}$

$$
=4.20 \times 10^{-3} \mathrm{~m}^{3} / \mathrm{s}
$$$$
=4.20 \mathrm{lit} / \mathrm{s}
$$

$$
=2 \times 4.20 \times 60 \times 60
$$

$=30240$ liters $=31000$ liters (approx) $=2$ times of Breadth

$$
\begin{aligned}
& =31000 \text { liters } \\
& =31 \mathrm{~m}^{3} \\
& =2.5 \mathrm{~m} \\
& =5 \mathrm{~m} \\
& =2.5 \mathrm{~m} \\
& =31.25 \mathrm{~m}^{3} \text { or } 31250 \text { liters }
\end{aligned}
$$

Assuming diameter of pipe $=6 \mathrm{~cm}$

Head loss due to friction for the $10 \mathrm{~m}$ length (Here, $\mathrm{h}=2.5 \mathrm{~m}$ and $\mathrm{L}=10 \mathrm{~m}$ )

TABLE 18. Head loss due to friction for the $10 \mathrm{~m}$ length, TABLE 19 . Head loss due to friction for the $10 \mathrm{~m}$ length, morning \& evening afternoon

\begin{tabular}{|c|c|c|c|c|}
\hline \multicolumn{5}{|c|}{$\mathrm{T}=23.8^{\circ}$, Morning \& Evening } \\
\hline $\mathrm{V}(\mathrm{m} / \mathrm{s})$ & $\mathrm{Q}\left(\mathrm{m}^{3} / \mathrm{s}\right)$ & $\mathrm{Re}$ & $\mathrm{F}$ & $\mathrm{h}_{\mathrm{f}}(\mathrm{m})$ \\
\hline 5.99 & 0.0169 & 3.85 & $3.17 \times$ & 3.86 \\
& & $\times 10^{5}$ & $10^{-3}$ & \\
\hline
\end{tabular}

\begin{tabular}{|c|c|c|c|c|}
\hline \multicolumn{5}{|c|}{$=28^{\circ}$, Afternoon } \\
\hline $\mathrm{V}(\mathrm{m} / \mathrm{s})$ & $\mathrm{Q}\left(\mathrm{m}^{3} / \mathrm{s}\right)$ & $\mathrm{Re}$ & $\mathrm{F}$ & $\mathrm{h}_{\mathrm{f}}(\mathrm{m})$ \\
\hline 5.99 & 0.0169 & $\begin{array}{c}4.24 \\
\times 10^{5}\end{array}$ & $\begin{array}{c}3.09 \\
\times 10^{-3}\end{array}$ & 3.77 \\
& & & \\
\hline
\end{tabular}


Therefore maximum head loss due to friction

Therefore the total height of overhead tank

Therefore total head of overhead tank should be 18 meters.

\section{PUMP OPERATING COST}

For $20 \mathrm{~m}$ head $1.02 \mathrm{hp}$ pump can lift

Therefore for 2 hours it can pump

For 31000 liter capacity tank total hp required

Pump rating as $3 \mathrm{hp}$, assuming $80 \%$ efficiency input power is [5.a].

$3.75 \mathrm{HP}$

One unit

Cost of 1 unit as per Assam Electricity Board

$$
\begin{aligned}
& =3.86 \mathrm{~m} \\
= & 14.04+3.86 \\
= & 17.90 \mathrm{~m} \\
= & 18 \mathrm{~m} \text { (approx) }
\end{aligned}
$$

If useof the pump is for two hours morning, noon and evening each, total of $6 \mathrm{hrs} /$ day.

Therefore pump operation cost

$$
\begin{aligned}
& =84 \mathrm{lit} / \mathrm{min} \\
& =10080 \text { liters } \\
& =31000 / 10080 \\
& =3.07 \mathrm{hp} \\
& =3 \mathrm{hp} \text { (approx) }
\end{aligned}
$$

$$
=2.81 \mathrm{KW}
$$$$
=1 \mathrm{KWh}
$$$$
=\text { Rs 4.20/unit }
$$
$=\operatorname{Rs}(6 \times 31 \times 2.81 \times 4.20)$

Here, $31=$ no. of days in a month

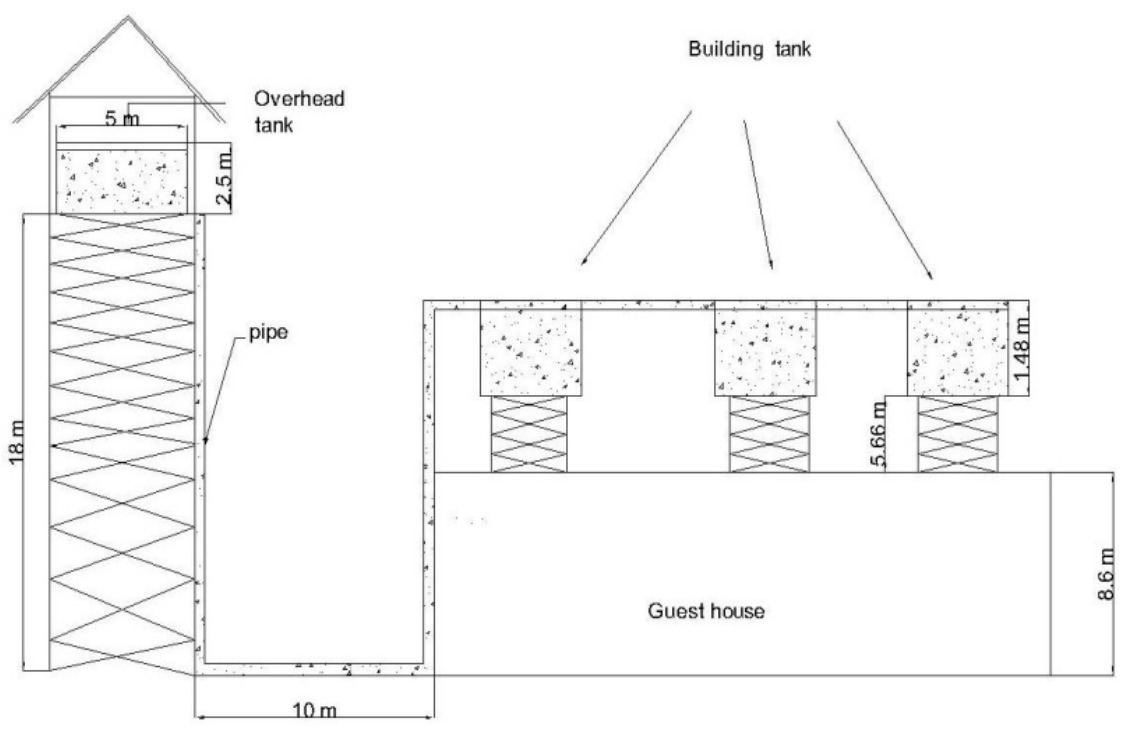

Fig. 5. Design of overhead tank

\section{CONCLUSION}

One of the most typical and common problem faced by the Engineers dealing with pipe flow system is the calculation of required head for a system and measuring the losses of head. According to the Bernoulli's equation the energy and the mass must remain conserved throughout the conveyance of water. But in practical it is not so, because of the various factor causing the head loss in the pipe system. This may be due to frictional forces on the water flowing in the surface of the pipe, or by the fluid itself, may be due to the different shape sizes of the pipe fittings.

In the study consideration was on the major losses because with comparison to it, minor losses such as due to bends in the pipes, sudden contraction or sudden expansion, are very small. Though it can be calculated by measuring equivalent length and further can be added to the overall length of the pipe. Thus, by measuring the head losses and height of the guest house it was concluded that an overhead tank with a height of $18 \mathrm{~m}$ 
should be designed which can be located at a distance of $10 \mathrm{~m}$ form the guest house. Also the height of the guest house tank should be increase more with $5.57 \mathrm{~m}$ which will give the required head to supply water with adequate pressure.

\section{REFERENCES}

[1] Walski T. M., Chase D. V., Savic D. A., et al. Advanced Water Distribution Modeling and Management[M]. Waterbury:Haested Press, 2003.

[2] Zhiqiang Yu. Research on Water Distribution System Hydraulic Model Software and Sampling Desigh for Calibration[D]Tianjin: Tianjin University, 2010.

[3] Shirong Xu, Zhenhua Qiu. Theoretical Calculation and Computing Applications of Water Distribution Network [M] Hunan: Hunan University Press, 1997.

[4] Sumer Derya, Lansey Kevin. Effect of Uncertainty on Water Distribution System Model Design Decisions[J]. Journal of Water Resources Planning and Management. 2009, 135(1):38-47

[5] Hongbin Zhao. Water Supply Systems Theory and Analysis[M] Beijing: China Architecture and Building Press, 2003.

[6] R.S. Khurmi, S. Chand \& Company Ltd. (1986) 'A Text book of Hydraulics, Fluid Mechanics and Hydraulic Machines'.

[7] Wong LT, Mui KW. Modeling water consumption and flow rates for flushing water systems in high-rise residential buildings in Hong Kong. Build Environ 2007;42(5):2024-34.

[8] Wong LT, Mui KW. Stochastic modelling of water demand by domestic washrooms in residential tower blocks. Water Environ J 2008;22(2):125-30.

[9] Plumbing Services Design Guide, 2nd ed. England, Hornchurch: The Institute of Plumbing; 2002.

[10] http://www.pipeflowcalculations.com/pipe-valve-fitting-flow/flow-in-pipes.php.

[11] Kaya D, Yagmur EA, Yigit KS, Kilic FC, Eren AS, Celik C. Energy efficiency in pumps. Energy Convers Manage 2008;49(5):166273.

[12] Wong LT, Mui KW. Epistemic water consumption benchmarks for residential buildings. Build Environ 2008;43(6):1031-5.

[13] http://www.EngineeringToolBox.com.

[14] Park SK, Miller KW. Random number generators: good ones are hard to find. Commun ACM 1988;31(10):1192-201.

[15] Dr. R.K. Bansal, Laxmi Publication Ltd 'A Text book of Fluid Mechanics and Hydraulic Machines'.

[16] R.K Rajput 'A textbook of hydraulic machines, Fluid mechanics and Hydraulic machines'. 